\title{
Shai Cohen, El poder de la palabra: la sátira política contra el Conde-Duque de Olivares, Madrid, CSIC [Anejos de la Revista de Literatura, 90], 2019, 181 pp. ISBN: 978-84-00-10492-4
}

\section{José Elías Gutiérrez Meza}

https://orcid.org/0000-0003-0999-9319

Universidad Tecnológica del Perú / Pontificia Universidad Católica del Perú PERÚ

c21882@utp.edu.pe / jegutierrezm@pucp.edu.pe

[Hipogrifo, (issn: 2328-1308), 9.2, 2021, pp. 1133-1135]

Recibido: 07-06-2021 / Aceptado: 16-06-2021

DOI: http://dx.doi.org/10.13035/H.2021.09.02.77

El valido de Felipe IV, Gaspar de Guzmán, más conocido como el conde-duque de Olivares, fue uno de los políticos españoles más cuestionados de los primeros siglos de la España moderna. Por ello, durante su privanza, circularon un conjunto de sátiras anónimas que, centradas en las controversias provocadas tanto por su actuación política como personal, lo acusaban de ser el principal responsable del mal gobierno en la España del "Rey Planeta". El presente volumen propone no solo una antología de dicha poesía satírica, la cual evidencia la opinión pública desfavorable hacia Olivares, sino que también ofrece un estudio de los principales aspectos de esta literatura, así como un acercamiento a su contexto histórico.

Compuesta por un total de veintiocho poemas, esta antología ha sido resultado de una minuciosa búsqueda, realizada por Shai Cohen, en diferentes bibliotecas de Francia, Inglaterra y España. Junto con poemas inéditos, en ella se han incluido otros poemas que, si bien ya habían sido publicados, presentan importantes variantes. Asimismo, como su editor apunta, esta sátira proliferó sobre todo en la década de los cuarenta, es decir, en los últimos años de la privanza del conde-duque. Sobresalen especialmente en la producción de esta poesía los años de 1643, en que los críticos del valido celebraron su retirada de la privanza, y de 1645, cuando el caído político se trasladó a Toro, su destino final. 
El libro se encuentra dividido en tres capítulos. El primero de ellos está dedicado al contexto histórico de Olivares. Tras repasar la biografía del valido, Cohen examina su relación con los ars gubernandi, los cuales no solo fueron una importante lectura en la formación del privado de Felipe IV, sino que también el propio Olivares fue autor de uno de ellos: El gran memorial (1624). Este compendio de diversos escritos y epístolas, algunos redactados personalmente, otros seleccionados por el conde-duque, fue compuesto para guiar al entonces joven rey. En tercer lugar, el estudioso se detiene en el uso de la propaganda, entendida como el intento de dirigir la opinión pública, la cual fue una de las constantes preocupaciones del valido. Por ello, recurrió a la literatura y puso a su servicio una cuadrilla de propagandistas, entre los cuales estuvieron autores señeros del Siglo de Oro español como Lope de Vega y Francisco de Quevedo. El objetivo de tales propagandistas no fue solo orientar a la opinión pública de acuerdo con los proyectos e intereses de Olivares, sino también reescribir y configurar la futura historia. Tal conciencia sobre el poder de la propaganda explica también que en 1627 el conde-duque ampliase la censura secular a todo tipo de impresos que tocasen materias de estado y de gobierno, ya que, como principal motor de la reputación, la propaganda era determinante para configurar la buena o la mala fama del gobernante. En este sentido, si bien Olivares no le prestó mucha importancia a su propia imagen y a las alusiones contra su persona que aparecían en las sátiras, sí se preocupó por cuidar y enaltecer constantemente la imagen de Felipe IV.

En el segundo capítulo, Cohen propone un acercamiento a las características literarias de esta poesía satírica. Después de reflexionar sobre el género de estas composiciones, aborda la relación entre realidad y ficción. Este aspecto resulta relevante, pues en la figura de Olivares se mezclan historia y literatura. Por ello, es importante no olvidar que, si bien estas composiciones recogen datos no solo verídicos, sino también confirmados, tales datos son expresados desde una perspectiva que tiende a la exageración y que, sobre todo, persigue los intereses personales de sus respectivos autores, de ahí que sea equivocado pretender usar la sátira antiolivarista, arma de la oposición contra el privado, como una fuente histórica para conocer los acontecimientos relacionados con su gobierno.

La anonimia es otra característica de esta poesía. Además de ser una condición básica para que sus autores pudiesen arremeter contra el poderoso valido, su carácter satírico suponía una invitación a la comicidad y la diversión que se extendía a un público amplio o, mejor, a diferentes públicos, ya que la ausencia de autores singulares evitaba que esta literatura se limitara a círculos cultivados. No obstante, se observan también falsas o dudosas atribuciones, puesto que colocar estas composiciones bajo el nombre de prestigiosos autores de la época, como es el caso de Francisco de Quevedo, redundaba en los intereses crematísticos de quienes las distribuían. Por otra parte, por la repetición de determinados temas (por ejemplo, la caída del conde-duque), la intertextualidad es recurrente en esta sátira y se percibe también en el repertorio de imágenes del que estas composiciones se servían. Así sucede con el término "gallinero", utilizado para referirse al Palacio del Buen Retiro, o con la identificación de Olivares con el diablo y sus diferentes nombres (Luzbel, Lucifer, Belcebú, etc.). 
En el segundo capítulo se propone también una revisión de los contenidos de esta literatura y del estilo de los poemas de la antología. Con respecto a sus contenidos, además de los acontecimientos relacionados con la esfera pública del privado (por ejemplo, la Unión de Armas y la edificación del Palacio del Buen Retiro), esta sátira disparó sus dardos contra el ámbito personal (la vida amorosa y familiar) de Olivares. Tales ataques partían de la idea de que, si el conde-duque no podía respetar ciertos códigos de la moral cristiana, él no debía encargarse del gobierno. Por ello, eran recurrentes las referencias a su hijo ilegítimo Julián de Valcárcel, así como al episodio del Convento de San Plácido, probablemente la más disparatada acusación hecha en su contra. Se le imputaba haber realizado en dicho convento benedictino un pacto con el Demonio para tener un hijo y, asimismo, entregarse a los placeres carnales con su mujer, Inés de Zúñiga, y las monjas del claustro. En lo relacionado al estilo, se examina el léxico empleado en los poemas. Al respecto, junto con el lenguaje soez, basado en insultos y maldiciones, aparecen en ellos múltiples referencias bíblicas que giran en torno a los personajes que representan la traición, la manipulación y la tiranía, como es el caso de Caín, Judas y Amán. Finalmente, tras una revisión de las figuras retóricas más recurrentes, se describen las características métricas de las composiciones seleccionadas.

El tercer y último capítulo consiste en la antología. Precedidos por la descripción de los testimonios utilizados como fuentes para esta selección, se disponen los veintiocho poemas numerados y cuidadosamente anotados. Dicha anotación ilumina estos textos oscuros y difíciles para el lector contemporáneo en lo que se refiere no solo a aclarar los términos y expresiones lingüísticas de la época, sino también a explicar las numerosas y frecuentemente crípticas referencias a los personajes y acontecimientos vinculados con la persona y las acciones del condeduque. Gracias a las notas fijadas por Cohen y el estudio preliminar de los dos primeros capítulos arriba expuesto, incluso el lector menos familiarizado con el valido del Rey Planeta podrá reconstruir y apreciar la crítica antiolivarista cifrada en estas composiciones.

Como se ve, El poder de la palabra supone un aporte significativo y redondo al estudio de una de las dimensiones del valimiento de Gaspar de Guzmán: la crítica contra su gobierno y su figura expresada en la poesía satírica anónima cultivada durante su privanza. Contextualizar el entorno intelectual, político y social que dio origen a la sátira antiolivarista sin duda ha sido una tarea larga y ardua; por ello, como el prestigioso hispanista John Elliott apunta en el prólogo compuesto para presentar este libro, estamos en deuda con Shai Cohen. 